\title{
What do we know about Pterois volitans in the Reefs of Veracruz, Mexico?
}

\author{
Carlos González-Gándara* \\ Facultad de Ciencias Biológicas y Agropecuarias, Universidad Veracruzana, México
}

Submission: June 22, 2020; Published: July 06, 2020

Corresponding author: Carlos González-Gándara, Laboratorio de Arrecifes Coralinos, Facultad de Ciencias Biológicas y Agropecuarias, Universidad Veracruzana Carr Tuxpan-Tampico km 7.5, Col. Universitaria. CP 92860. Tuxpan, Veracruz, México.

\author{
Abstract \\ The state of knowledge of lionfish (P. volitans) in the reefs of Veracruz and the need to promote research to inform decision-making in \\ Veracruz's NPAs is presented. \\ Kewords: Lionfish; Veracruz; Gulf of Mexico \\ Abbreviations: LTRS: Lobos-Tuxpan Reef System; VRS: Veracruz Reef System; TRS: Los Tuxtlas Reef System; NPA: Natural Protected Areas
}

\section{Introduction}

Since its arrival to the Atlantic coast in 1985, the lionfish (Pterois volitans) has been studied for the threat it poses to native communities because it reduces fish abundance can unbalance reef trophic structure and affects regional biotic diversity. On the western coast of the Gulf of Mexico there are more than 100 reef structures distributed in three systems: the Lobos-Tuxpan Reef System (LTRS) in the north, the Veracruz Reef System (VRS) in the center, and the Tuxtlas Reef System (TRS) in the south of Veracruz. Knowledge of lionfish in these systems is practically limited to citing their presence. This note synthesizes the research results of $P$. volitans in the reefs of Veracruz and emphasizes the need to increase knowledge to inform decision making [1-4].

Genetic studies reveal that the lionfish population in Veracruz corresponds to the species $P$. volitans [5]. The first sighting of this species on the coast of Veracruz (western Gulf of Mexico) dates from 2011 in the VRS [6]. Subsequently, P. volitans has been documented as part of the ichthyofauna in the LTRS, VRS and TRS [7-10]. Despite the wide dissemination of the lionfish invasion in reef formations, research on this species in the reefs of Veracruz is very scarce and has been carried out exclusively in the VRS. Publications reveal that the size of $P$. volitans in Veracruz is $248.1 \pm 48.2 \mathrm{~mm}$ and the weight is $279.2 \pm 221.8 \mathrm{gr}$ [11]. Likewise, it presents endoparasites (trematodes, cestodes and nematodes) with a prevalence of less than $30 \%$ and heavy metals in the tissues ( $\mathrm{Cd}=0.03, \mathrm{~Pb}=0.66, \mathrm{~V}=7.3$ and $\mathrm{Zn}=0.43 \mathrm{mg} \mathrm{kg}-1$ dry weight) whose concentrations do not exceed official standards $[12,13]$.

Analysis of the stomach contents of lionfish caught on the soft bottoms around the VRS shows that $95.4 \%$ correspond to fish living in association with the substrate (Synodontidae, Serranidae and Paralichthydae) and $4.6 \%$ to crustaceans and molluscs [14]. These authors cite that the density of lionfish in the area is low but do not provide any specific data. The knowledge of the distribution and abundance of lionfish in the reefs of Veracruz is basic to establish control policies for its population. Because lionfish consume fish that live closely linked to the substrate whose richness and abundance is greater in areas with high structural complexity [15-18]. Among the threatened species in Veracruz's reefs are Tigrigobius redimiculus, endemic to Veracruz and Halichoeres burekae, endemic to the Gulf of Mexico [19, 20].

\section{Conclusion}

The condition of Natural Protected Areas (NPA) of the VRS and the LTRS as well as the proposal as NPA of the TRS [21-23] makes it essential to promote basic research, which will allow the elaboration of a diagnosis of the population of $P$. volitans in the reef ecosystems of Veracruz, as well as to evaluate the effect that 
its presence generates on the reef communities. Based on this information, the authorities of the NPAs will be able to generate adequate strategies for the management and control of the lionfish population in the reefs of Veracruz.

\section{References}

1. Cure K, Benkwitt C E, Kindinger T L, Pickering E A, Pusack T J, et al (2012) Comparative behavior of red lionfish Pterois volitans on native Pacific versus invaded Atlantic coral reefs. Marine Ecology Progress Series 467: 181-192.

2. Albins M A (2015) Invasive Pacific lionfish Pterois volitans reduce abundance and species richness of native Bahamian coral-reef fishes. Marine Ecology Progress Series 522: 231-243.

3. Arias-González J E, González-Gándara C, Cabrera J L, Christensen V (2011) Predicted impact of the invasive lionfish Pterois volitans on the food web of a Caribbean coral reef. Environmental Research 111(7): 917-925.

4. Ortiz-Lozano L, Colmenares-Campos C, Gutiérrez-Velázquez A L (2019) Arrecifes sumergidos y su relevancia para el corredor arrecifal del suroeste del Golfo de México. In: Granados-Barba A, Ortiz-Lozano L, González-Gándara C, Salas-Monreal D (Eds.). Estudios científicos en el corredor arrecifal del suroeste del Golfo de México. EPOMEX, Campeche, México, Pp. 1-36.

5. Guzmán-Méndez IA, Rivera-Madrid R, Planes S, Boissin E, Cróquer A, et al. (2019) Genetic connectivity of lionfish (Pterois volitans) in marine protected areas of the Gulf of Mexico and Caribbean Sea. Ecology Evolution 10(9): 3844-3855.

6. Santander-Monsalvo J, López-Huerta I, Aguilar-Perera A, Tuz-Sulub A (2012) First record of the red lionfish (Pterois volitans) off the coast of Veracruz, México. BioInvasions Rec 1(2): 121-124.

7. González-Gándara C, De la Cruz-Francisco V, Salas-Pérez JJ, DomínguezBarradas C (2012) Lista de los peces de Tuxpan Veracruz, México. Revista Científica UDO Agrícola 12(3): 675-689.

8. González-Gándara C (2015) Peces del arrecife Blake, Veracruz, México: Inventario, distribución y afinidades zoogeográficas. Ecosist Recur Agropec 2(4): 87-98.

9. Pérez-España H, Bello-Pineda J, Ávila-Santiago P, Berumen-Solorzano P, Melo-Merino S, et al. (2015) Monitoreo del Parque Nacional Sistema Arrecifal Veracruzano: Segunda Etapa. Universidad Veracruzana, Instituto de Ciencias Marinas y Pesquerías. Informe final SNIBCONABIO, proyecto GM004, México D.F.

10. González Gándara C, Domínguez-Barradas C, De la Cruz-Francisco V, Solís-Marín F A, Carricart-Ganivet J P (2015) Esponjas, corales escleractinios, equinodermos y peces de arrecifes coralinos del norte y sur de Veracruz. Universidad Veracruzana. Facultad de Ciencias Biológicas y Agropecuarias. Informe final SNIB-CONABIO, proyecto No. JF124. México D.F.
11. Reyes-Aguilar A R, Castañeda-Chávez M R, Montoya-Mendoza J, LangoReynoso F, Zamudio-Alemán R, et al. (2018) Morphometry of Pterois volitans (Linnaeus, 1758) in the Veracruz Reef System in the Central Zone of the Gulf of Mexico. Oceanogr Fish Open Access J 5(5): 555673.

12. Montoya-Mendoza J, Camarena-Luhrs T, Castañeda-Chávez M R, LangoReynoso F (2017) Helminth Parasites of Red Lionfish, Pterois volitans from the Veracruz Coral Reef System, Mexico, Southern Gulf of Mexico. Journal of Agricultural Science 9(11): 30-33.

13. Montoya-Mendoza J, Alarcón-Reyes E, Castañeda-Chávez M R, LangoReynoso F, Zamudio-Alemán R E (2019) Heavy metals in muscle tissue of Pterois volitans from the Veracruz Reef System National Park, Mexico. Int J Environ. Res Public Health 16(23): 4611.

14. Aguilar-Medrano R, Vega-Cendejas M E (2020) Size, weight, and diet of the invasive lionfish Pterois volitans (Linnaeus, 1758) on the southern coast of Veracruz, Gulf of Mexico. Ciencias Marinas 46(1): 57-64.

15. Morris Jr J, Akins J L (2009) Feeding ecology of invasive lionfish (Pterois volitans) in the Bahamian archipelago. Environmental Biology of Fishes 86: 389-398.

16. Valdez-Moreno M, Quintal-Lizama C, Gómez-Lozano R, García-Rivas M C (2012) Monitoring an alien invasion: DNA barcoding and the identification of lionfish and their prey on Coral Reefs of the Mexican Caribbean. PLoS ONE 7(6): e36636.

17. Pabón-Quintero P, Acero P A (2016) Ecología trófica del invasor pez león Pterois volitans en el Caribe colombiano: impacto sobre familias ícticas de Santa Marta y San Andrés. In: Campos-Campos N H, AceroPizarro A (Eds.). Contribuciones en ciencias del mar de la Universidad Nacional de Colombia 2015. Universidad Nacional de Colombia, Bogotá, Colombia, Pp. 52-74.

18. Andradi-Brown D A (2019) Invasive Lionfish (Pterois volitans and $P$. miles) Distribution, Impact, and Management. In: Loya Y, Puglise K, Bridge T (Eds). Mesophotic Coral Ecosystems, Springer, Switzerland, Pp. 931-941.

19. Taylor M S, Akins L (2007) Two New species of Elacatinus (Teleostei: Gobiidae) from the Mexican Coast of the Gulf of México. Zootaxa 1425(1): 45-51.

20. Weaver D C, Rocha L A (2007) A new species of Halichoeres (Teleostei: Labridae) from the western Gulf of Mexico. Copeia 4: 798-807.

21. Comisión Nacional de Áreas Naturales Protegidas (2017) Programa de Manejo Parque Nacional Sistema Arrecifal Veracruzano, CONANP, México P. 347.

22. Comisión Nacional de Áreas Naturales Protegidas (2014) Programa de Manejo Área de Protección de Flora y Fauna Sistema Arrecifal LobosTuxpan, CONANP, México p. 175.

23. Comisión Nacional de Áreas Naturales Protegidas (2018) Estudio Previo Justificativo para la declaratoria del Área de Protección de Flora y Fauna Arrecifes de Los Tuxtlas, CONANP, México, p.180. 
CC (i) This work is licensed under Creative

DOI: 10.19080/OFOAJ.2020.12.555828

\section{Your next submission with Juniper Publishers} will reach you the below assets

- Quality Editorial service

- Swift Peer Review

- Reprints availability

- E-prints Service

- Manuscript Podcast for convenient understanding

- Global attainment for your research

- Manuscript accessibility in different formats

( Pdf, E-pub, Full Text, Audio)

- Unceasing customer service

Track the below URL for one-step submission https://juniperpublishers.com/online-submission.php 